\title{
THE AUTHENTIC WILL BETWEEN THEORY AND PRACTICE
}

\section{D.-G. IONAŞ, C.DINU}

\section{Diana-Geanina IONAȘ}

Transylvania University of Brasov

Faculty of Law

*Correspondence:

E-mail: diana_ionas@yahoo.com

\section{Cristina DINU}

Transylvania University of Brasov

Faculty of Law

\begin{abstract}
A will is the unilateral, personal and revocable judicial act through which a person, called a testator, rules for the time when he is no longer alive. A specific form of will regulated by law is the authentic will. It is characterized by the fact that the will of the testator is drawn up in authentic form, the testator is advised, and thus the will acquires the specific force of the authentic act. What differentiates the authentic will from other forms of will is the authentication procedure, which is described within this article. This procedure ensures the protection of the testator's will, the full understanding of the effects of a legal act with death cause.
\end{abstract}

KEYWORDS: will, authentication, public notary, proof

\section{INTRODUCTION.}

The will is the unilateral, personal and revocable judicial act, by which a person, called a testator, rules, in any form required by law, for the time when he is no longer alive ${ }^{1}$.

Deriving from the Latin word testis (witness), the testament was a permanent preoccupation of doctrine, being seen as a rigorous inventory of goods, but also as an act of last will by which the destination of certain goods is established, thus offering "the most convincing, most sincere and most exemplifying expression of what man understands by property and its destiny"2.

By discussing the critiques phrased in specialty literature, the Romanian lawmaker correctly described, within the new Civil Code, the essential distinction between legate and testament, thus correctly appreciating that the will is merely the act of final will of the testator which can comprise provisions of patrimonial character, namely legates, as well as non patrimonial provisions. As opposed to the phrasing of the Romanian lawmaker within article 1035 of the Civil Code, we believe that stating legates is not of the essence of the will, it pertains to its nature, as the will contains exclusively patrimonial provisions which will come into effect after the death of the testator.

Thus, the will is merely the legal support of the manifestation of will of the testator, being a complex and heterogeneous legal act, which contains more legal acts, independent as legal regime and purpose ${ }^{3}$. Being a legal act, namely a manifestation of will with the purpose of

\footnotetext{
${ }^{1}$ Article 1034 of the Civil Code passed by Law no 287/2009 regarding the new Civil Code, republished in the Official Bulletin part I no 505 of July $15^{\text {th }}, 2011$

2 The National Union of Public Notaries of Romania, Wills - an anthology by GeorgetaFilitti, Notarom Publishing House, Bucharest, 2007, page 19

${ }^{3}$ M. Popa, Civil law. Succession, Oscar Print Publishing House, Bucharest, 1995, page 68
} 
causing legal effects, the will must be seen as an instrumentum, as well as a negotium; our opinion is that the idea according to which the will is merely the proof of the legate 4 is unacceptable; furthermore, the lawmaker regulates the possibility to test in regard to other aspects except the patrimonial ones.

\section{THE NOTION OF THE AUTHENTIC WILL}

The authentic will is that testament which was authenticated by a public notary or by another person invested with public authority by the state, according to the law ${ }^{5}$. Initially, the competence of authenticating a will belonged to the courts of law, as a result of subsequent changes of law the competence was given to public notaries.

The lawmaker expressly regulates in article 1043 first alignment of the new Civil Code the fact that the authentication of a will can be performed not only by a public notary, but also by another person invested by the state with public authority, without clearly stating who that person is. In our opinion, these people can be exclusively the heads of diplomatic offices and consular offices of Romania situated abroad, namely the consuls and ambassadors ${ }^{6}$.

Doctrine expressed the idea according to which the authentication of a will can be performed by a lawyer, given by the fact that a lawyer's activity includes drafting legal acts, attesting the identity of parties, content and date of acts which are to be authenticated ${ }^{7}$. We do not share this opinion as we do not share the opinion according to which the secretaries of local or communal councils where there are no public notaries are people invested with public authority $^{8}$; this opinion is shared by the High Court of Justice ${ }^{9}$. In justifying this opinion, we must first consider the provisions of article 17 of Law 36/1995 ${ }^{10}$ according to which the secretaries of local councils of cities and villages where there are no offices of public notaries

\footnotetext{
${ }^{4}$ O. Căpăţână, Gratuity in legal acts, Rosseti Publishing House, Bucharest, 2003, page 29; pertaining to this theory, we must mention that old French literature states the idea of interpreting the will both as an instrumentum and as a negotium - see D. Guevel, Successions. Liberalities, Armand Colin Publishing House, Paris, 2008, page 214

${ }^{5}$ The authentic will is acknowledged in most laws, much like the requirements of it being drafted by a notary and signed by the testator. In French law, the authentic will must be drafted by dictation of the testator, by two notaries or a notary assisted by two witnesses - article 971 of the French Civil Code. The witnesses must be people of age, able to understand the French language and able to sign. The legatees, the parents or relatives up until the fourth degree can't be witnesses. The will must be dictated to the notary or notaries who will write it by using legal terms according to the will of the testator. The witnesses must assist in the writing of the will. Subsequently, the will shall be read to the testator and it will be signed by the testator, the witnesses and the notary - see Cour de cassation - Première chambrecivile - Arrêt $\mathrm{n}^{\circ} 134$ du 1 février 2012 (10-31.129) and Cour de cassation - Première chambrecivile - Arrêt $\mathrm{n}^{\circ} 704$ du 29 juin 2011 (10-17.168), accessed at http://www.courdecassation.fr/jurisprudence_2/premiere_chambre_civile_568/134_1_22143.html 13.05.2014. In Austria, this certain type of will can be made in oral form before a court of law.

${ }^{6}$ However, this possibility is not new as, since 1944, by Law no 358/1994 for the authentication and legalization of documents, establishing a certain date and legalization of copies of documents, a law which was in force until 1960; it also unified the provisions of different laws regarding notary activity, it improved the procedure of authentication and investing of authenticated documents, it maintained the duties of the Public Notary and stated the right of diplomatic and consular offices to authenticate, legalize and invest documents presented by Romanian citizens abroad.

${ }^{7}$ C.S. Ricu, G.C. Frenţiu, D. Zeca, D.M. Cigan, T.V. Rădulescu, C.T. Ungureanu, G. Răducan, Gh. Durac, D. Călin, I. Ninu, Al. Bleoancă, The new Civil Code. Comments, doctrine and jurisprudence, second volume,Hamangiu Publishing House, Bucharest, 2012, page 169

${ }^{8}$ I. Genoiu, The right to inherit in the new Civil Code, C.H. Beck Publishing House, Bucharest, page 167

${ }^{9}$ By decision no 6257 of 2005 of the High Court of Justice seen at http://legeaz.net/spete-civil-iccj-2005/decizia6257-2005 on 11.08.2014 it was established that "the written document, signed on March $25^{\text {th }}, 1992$ by H.V. and H.C. before the secretary of Prisacani village of Iasi county, named a will is null as a testament as it violates the formalities stated by articles 858-860 of the Civil Code, thus it can't be assimilated to the hand written will, as it is not written, dated and signed by the testator. It is also not an authentic will, as it was not drafted in front of a notary."

${ }^{10}$ Law no 36/1995 of public notaries and notary activity, republished in the Official Bulletin, part I, no 444 of June $18^{\text {th }}, 2014$.
} 
perform, on the parties' request, the legalization of certain copies, except for private documents; similar are the provisions of article 78 first alignment of the same law, according to which the legal acts which require an ad validitatem authentic form will be drafted up by public notaries.

The reason for such an interpretation is extremely simple and derives form the importance of the act of final will and from the necessity of guaranteeing a freely expressed and non vitiated consent which can only be determined by an organ invested with public authority.

The authentic will has a series of advantages which pertain to the fact that: - it ensures certainty in regard to the person of the testator, as it is an authentic act and the procedure states that it is mandatory to identify the parties; it allows for the clear determination of the will of the testator, as he is advised - an obligation regulated by article 9 of Law no 36/1995 which states that the public notary is obliged to find out what is the real will of the testator; it avoids the inefficiency of clauses or the impossibility to execute them as a result of the testator disrespecting the imperative legal provisions; in this case, the notary must refuse the authentication of acts which are contrary to the law or good morals; it enjoys the proof force of authentic acts and, as a result, the task of proof belongs to the person who contests it; it is accessible to people who can't write or read or to the people who, due to infirmity or any other cause, are unable to sign, as authentication is possible by authorized interpreters and assistant witnesses; subsequent contestation is difficult, possible only by the procedure of declaring it fake; a copy of the document is permanently kept in the archive of the notary office thus it can't be stolen, hidden or destroyed by the interested parties; if it disappears, a duplicate can be obtained or it can be reconstructed under the conditions stated by law; the existence of the will is ensured by its registration in the General Evidence Register of Notaries ${ }^{11}$.

Thedisadvantagesof this type of will pertain mainly to the fact that it is somewhat expensive, as the testator must pay the notary fee; it also does not ensure the secret of the last will of the testator. In regard to this aspect, we must mention that information about the will can only be provided after the testator dies.

\section{THE PROCEDURE OF AUTHENTICATING OF A WILL}

The competence of authenticating of a will is general and belongs to any notary on Romanian territory, independent of the domicile of the testator or the place where the goods are situated. The exclusive competence established by article 12 of Law 36/1995 considers only the successor procedure, which is started by request, after the death of the testator.

The regulation of the new Civil Code is completed with the one of Law no 36/1995 republished which thoroughly describes the procedure of authentication of wills by public notaries.

Thus, according to legal provisions, all notary acts are drafted on demand. Although the rule is that of phrasing a verbal request, in the matter of wills, written from is mandatory in order to obtain an authenticated document. The demand is obviously phrased by the testator personally, as the will is an act which is essentially personal and can't be concluded by legal or conventional representative. The request must contain the identification information of the applicant and the mention regarding the fact that the will which is annexed to the request was drafted by the person itself or that the person has no written will and demands to dictate the content of his will to a public notary. Obviously, the request will be signed by the testator. In the special case of providing consent by an interpreter or authorized translator in the presence of assistant witnesses, the request will be signed by them as well.

In order to admit the request for authentication of the will, the public notary needs to verify if the act meets the conditions stated by law, namely capacity, consent, licit and determined object and the licit and moral cause.

\footnotetext{
${ }^{11}$ Founded in 2007, it records donations, authentic wills, revocation of wills as well as retraction of revocations.
} 
Before proceeding to the authentication of the will, the public notary must make all efforts in order to find out which is the real will of the testator, he must advise the testator and determine the purpose which the testator wished to achieve; all these are contained in the general obligation of advice as stated in article 9 of Law no 36/1995. During these verification stages, a special role is played by the verification of consent and all vices which affect consent and which attract the sanction of annulment of the drafted act.

As an example, we mention that one of the tasks of the public notary is to search whether the testator has reservation heirs, what is the connection between the testator and the potential legatee, what is the successor mass and so on; he must also advise the party by pointing out the effects of its act. Thus, the notary will show the applicant the inefficiency of drafting a will which states as universal legatees the children of the testator, in case there are no other heirs. Also, in case the testator requests the authentication of a will by which he leaves his family house to a certain legatee, the notary will have to be diligent in finding out if the testator wished to leave only the house or his entire fortune which contains the house. This aspect is especially important as it determines the qualification of the legate in a particular or universal one with all consequences which come from this qualification. The most important of consequences pertains to the particular legate in case there are no other heirs, thus requiring a different and difficult procedure of declaring a vacant inheritance.

Also, the public notary must verify if the testator, by his act of final will, aims to disrespect the imperative legal provisions, such as those of article 1009 first and second alignment of the Civil Code or those of article 1138 of the Civil Code regarding vacant inheritance ${ }^{12}$, in which case if the testator insists in authenticating the act in that certain form, the public notary will have to refuse the authentication of the act.

Also, during the authentication procedure, the public notary will have to inform the testator that he can be assisted by one or two witnesses, thus allowing him to decide whether to dictate his final will in their presence or not.

The provisions of Law no 36/1995 state two possibilities in drafting and authenticating wills:

- the first entails dictating the provisions of the will in front of the notary. Thus, the notary will register the will of the testator in legal terms, after fulfilling the legal obligation of advising and finding out the real will of the testator;

- a second possibility is that the testator presents an already written will, in which case, after the will is drafted, it will be read to the testator by the public notary. The hand written document will be kept in the archive of the notary office.

The will shall be drafted in Romanian, given the principle that all notary acts are drafted in Romanian ${ }^{13}$. By exception, on the justified request of the testator, the public notary can perform the act in another language only if he knows that certain language of after he is informed of the content by the interpreter, in which case a translated in Romanian copy signed by the translator will be attached to the file ${ }^{14}$. As opposed to the way the legal text is drafted, we appreciate that the possibility of drafting the will in another language is possible in any of the following ways:

- in case the public notary knows that certain language as it is his maternal language or he is an authorized translator, the will can be written after dictation or after the already drawn up will,

- in case the public notary doesn't know that certain language because it is not his maternal language or he is not an authorized interpreter or translator, the will can be written only based on the certified translation by an authorized interpreter which is attached to the original document.

\footnotetext{
${ }^{12}$ Vacant inheritances are given to the city or the village where the goods were located at the time the successor procedure began and become part of their private inventory. Any testamentary provisions which aim to remove this certain rule are considered to be unwritten clauses.

${ }^{13}$ Article 81 first alignment 1 of Law no 36/1995

${ }^{14}$ Article 81 fourth alignment 1 of Law no 36/1995
} 
The will shall be written with no blurred lines, free spaces, erase marks, the sums of money will be written in words and numbers, according to the general rules of drafting up notary acts.

The content of the will shall mention the existence or inexistence of reserve heirs, the fact that the testator was made aware of the legal provisions regarding the reserve, regarding the possibility to revoke the will and the legates as well as the possibility to be assisted by two witnesses.

After it is drawn up, the will shall be read by the testator or it will be read to the testator by the public notary, by making a mention of this aspect. By exception, when the testator is in a special situation which does not allow him to read the document himself of understand the content as explained by the public notary, an authorized interpreter or translator will sign along with the notary.

After the will is read, the testator must declare that it expresses his final will; afterwards, the will is signed by the testator, in case the testator was assisted by one or two witnesses, they will also sign the will. The signature represents the exteriorization of consent and must be applied on the document in front of the public notary. In case the testator is deaf, mute, deafmute but able to read, he will write, prior to signing the will, the following mention "I consent with the present document which I have read". In case he can't read, the will shall be signed by the interpreter.

The force of the authentic will resides in the authentication procedure of the document which means the procedure was completed. It must contain the mandatory mentions as stated in article 83 of Law no 36/1995, but also some special mentions regarding:

- fulfilling the formalities requested by article 1044 of the Civil Code as described above

- the identification information of assistant witnesses ${ }^{15}$ and the reason for which the testator did not sign the document personally

- the identification information of the authorized interpreter or translator

- the identification information of the lawyer who assisted the party

- mentions regarding the normal procedure of obtaining consent in special situations.

Disrespecting the provisions of article 83 of Law no 36/1995, as well as the special ones, is sanctioned with annulment, if they can't be interpreted and have caused damage which can't be removed in any other way.

The authentication is drafted along with the will. There are special situations in which the consent of the testator is taken outside the headquarters of the office (for example, at the domicile of the testator or even in the medical facility where the testator is admitted) and the authentication document is drafter subsequently at the public notary office. If the testator is still alive during this interval, this aspect is irrelevant. In the unfortunate case in which case the testator dies between the time the will is signed and the time it is authenticated, the doctrine is unanimous in stating that the authentication document can't no longer be signed, as by the death of the testator, the successor transmission has already operated, and the existing will did not meet the conditions required by law for a personally signed will, as it was not written and signed by the testator, nor those of an authentic will, as it was not authenticated by the public notary.

The authentication document must expressly mention the year,month,day and hour even the minute when the document was authenticated.

\section{THE REGISTRATION AND PROVING FORCE OF THE AUTHENTIC WILL}

In order to inform people with legitimate interest, but also in order to ensure the respect of the will of the testator, the notary who authenticates the will is required to register the will in the National General Evidence Register, electronically held by the Public Notaries Association of

\footnotetext{
15 The following people can't be assistant witnesses: people under the age of 18, people who are either a party or the beneficiary of the act, people who, as a result of physiological or physical deficiencies are not able to assist as witnesses, people who can't read or people who can't sign for any reason.
} 
Romania according to the law ${ }^{16}$. Information regarding the existence of a will can be provided to those who justify legitimate interest but only after the testator dies. Proof of death can be made with the death certificate.

In case the will contains certain provisions regarding the acknowledgement of a child, the public notary is obliged to communicate a copy of the will to the General Evidence of Population Service within 10 days of the authentication of the will.

The authenticated notary document is full proof, in regard to any person, until it is declared a fake, in regard to the facts personally acknowledged by the person who authenticated the will. The declaration of parties, as stated in thenotary document, represents proof until contrary argument, between the parties, as well as in regard to other people.

\section{CONCLUSIONS}

The will is a legal act of significant importance through which the testator "arranges" its patrimony after his death. The importance of this act is acknowledged and provided by the lawmaker through the fact that it can be drafted in authentic form. The necessity of the authentic form is completed by an extremely thorough procedure which is meant to ensure the understanding by the testator of the importance of his act as well as the subsequent respect of his final will.

\section{BIBLIOGRAPHY:}

C.S. Ricu, G.C. Frenţiu, D. Zeca, D.M. Cigan, T.V. Rădulescu, C.T. Ungureanu, G. Răducan, O. Căpăţână, Gratuity in legal acts, Rosseti Publishing House, Bucharest, 2003;

Gh. Durac, D. Călin, I. Ninu, A1. Bleoancă, The new Civil Code. Comments, doctrine and jurisprudence, second volume,Hamangiu Publishing House, Bucharest, 2012;

I. Genoiu, The right to inherit in the new Civil Code, C.H. Beck Publishing House, Bucharest;

M. Popa, Civil law. Succession, Oscar Print Publishing House, Bucharest, 1995.

***Civil Code passed by Law no 287/2009 regarding the new Civil Code, republished in the Official Bulletin part I no 505 of July $15^{\text {th }}, 2011$;

***The National Union of Public Notaries of Romania, Wills - an anthology by GeorgetaFilitti, Notarom Publishing House, Bucharest, 2007.

\footnotetext{
${ }^{16}$ The provision of the new Civil Code is not entirely new, as the Ilfov Tribunal had, ever since 1944, an archive of authentic and mystical wills, started as a result of the Law-Decree no 358/1994 for the authentication and legalization of all documents, for establishing a certain date and legalizing copies of certain documents, as published in the Official Bulletin no 152/2 of July 1944, which registered all wills which were authenticated by public notaries of judges.
} 